\title{
The Biosynthesis of a Choline Nucleotide by a Cell-free Extract from Streptococcus pneumoniae
}

\author{
By IAN R. POXTON AND DAVID J. LEAK* \\ Microbiological Chemistry Research Laboratory, The University of \\ Newcastle upon Tyne, Newcastle upon Tyne NEI ${ }_{7} R U$
}

(Received 19 October 1976)

\begin{abstract}
SUMMARY
Choline, a component of the wall teichoic acid of Streptococcus pneumoniae, was converted to cytidine diphosphocholine via choline phosphate by enzymes which were identified in cell-free extracts of the pneumococcus. The first enzyme, choline kinase, was investigated in some detail. It appeared to have a $\mathrm{pH}$ optimum of 7.3 to 7.4 and was stimulated by $\mathrm{Mg}^{2+}$. Kinetic studies gave an apparent Michaelis constant $\left(K_{\mathrm{m}}\right)$ for ATP of I mM, and for choline of $0.19 \mathrm{~mm}$, with

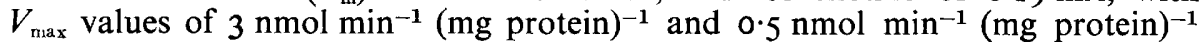
respectively. The second enzyme, CDPcholine pyrophosphorylase was specific for CTP and had a requirement for $\mathrm{Mg}^{2+}$ with an optimum at $7 \mathrm{mM}$.
\end{abstract}

\section{INTRODUCTION}

Choline, a nutritional requirement of Streptococcus pneumoniae, is essential for the normal functioning of the bacterium (Rane \& Subbarow, I940; Tomasz, I968). It is utilized as a structural component of the wall (C-) teichoic acid (Tomasz, 1967; Brundish \& Baddiley, I968) and of the pneumococcal Forssman antigen (Briles \& Tomasz, I973) but not in phospholipid biosynthesis. Structural analogues of choline, such as ethanolamine, can replace it as a growth requirement but several properties of the organism then become altered, e.g. (i) the daughter cells become unable to dissociate completely, forming chains of several hundred cells, (ii) the bacterium becomes resistant to both autolysis and detergentinduced lysis, and (iii) it is unable to undergo genetic transformation (Tomasz, I968; Tomasz et al., 1975).

This study reports the biosynthesis of cytidine diphosphocholine (CDPcholine) from choline in a cell-free system of $S$. pneumoniae. A similar pathway has been proposed in brewers' yeast which utilizes choline as a component of phosphatidylcholine (lecithin), one of the major phospholipids of this organism. This first enzyme of the pathway in yeasts, the choline kinase, has been investigated in some detail (Brostrom \& Browning, 1973) and is compared here with the pneumococcal enzyme.

\section{METHODS}

Materials. [methyl $\left.-^{3} \mathrm{H}\right]$ Choline chloride was purchased from The Radiochemical Centre, Amersham. [methyl $\left.{ }^{3} \mathrm{H}\right]$ Choline phosphate was synthesized chemically from $\left[\right.$ methyl $\left.{ }^{3} \mathrm{H}\right]-$ choline chloride by the method of Riley (1944), except that it was purified by preparative electrophoresis on Whatman $3 \mathrm{MM}$ paper in buffer B instead of by precipitation and

\footnotetext{
* Present address: Molecular Sciences Department, University of Warwick, Coventry CV4 7AL.
} 
recrystallization of the calcium salt. Unlabelled choline chloride and CDPcholine were from Sigma, and choline phosphate from Boehringer.

Growth of organism. Streptococcus pneumoniae ATCCI 22I 3 was maintained on blood agar slopes at $4{ }^{\circ} \mathrm{C}$ and subcultured at monthly intervals.

For preparation of the crude enzyme, batches of the organism (15 l) were grown in a laboratory fermenter (L.H. Engineering, Stoke Poges, Berkshire) in a medium containing $450 \mathrm{~g}$ brain heart infusion and $35 \mathrm{~g}$ neopeptone (both Difco). The inoculum was $50 \mathrm{ml}$ of an overnight culture. Incubation was at $37{ }^{\circ} \mathrm{C}$ with gentle stirring (I.5 rev. $\mathrm{min}^{-1}$ ) and automatic addition of $5 \mathrm{M}-\mathrm{NaOH}$ to maintain the $\mathrm{pH}$ at $7 \cdot 2$. After $\mathrm{I} 6 \mathrm{~h}$, sterile glucose was added to give a final concentration of $\mathrm{r} \%(\mathrm{w} / \mathrm{v})$, and incubation was then continued with stirring at $3.5 \mathrm{rev}$. $\mathrm{min}^{-1}$. Growth was monitored spectrophotometrically at $600 \mathrm{~nm}$ and cultures were harvested at an $E_{600}$ of $2 \cdot 0$ in a Sorvall continuous flow centrifuge at $4{ }^{\circ} \mathrm{C}$.

Cultures (I00 ml) were also grown in the synthetic medium of Tomasz (I964) using $0.5 \%(\mathrm{w} / \mathrm{v})$ casein hydrolysate instead of individual amino acids.

Preparation of crude enzyme. Harvested bacteria were washed with $0.7 \%$ (w/v) $\mathrm{NaCl}$ in Io mM-Tris/ $\mathrm{HCl}$ buffer, $\mathrm{pH} 7 \cdot 5$, and disrupted with no. I I Ballotini beads in a Braun homogenizer in $0.9 \% \mathrm{NaCl}$. Walls and unbroken cells were removed by centrifuging at $6000 \mathrm{~g}$ for Io min at $4{ }^{\circ} \mathrm{C}$. The supernatant fluid was used as the crude enzyme.

Analytical methods. The protein content of cell-free extracts was determined by the method of Lowry et al. (I95I). Choline phosphate and CDPcholine were detected on paper by the Dragendorf spray reagent (Bregoff, Roberts \& Delwiche, 1953). High voltage electrophoresis was performed in a Shandon Southern HVE apparatus model L24 (Shandon Southern Instruments, Camberley, Surrey) on Whatman no. I or $3 \mathrm{MM}$ papers using the following buffers: buffer $\mathrm{A}, 8 \cdot 0 \%(\mathrm{w} / \mathrm{v})$ formic acid, $\mathrm{pH} \mathrm{I} \cdot 8$; buffer $\mathrm{B}$, pyridine/acetic acid/water (5:5:190, by vol.), $\mathrm{pH}_{4} 7$. Descending paper chromatography on Whatman no. I paper was carried out in solvent $\mathrm{C}$ : ethanol/0.5 M-ammonium acetate, $\mathrm{pH} 3 \cdot 8$ (15:6, v/v).

Assay of $\left[\right.$ methyl $\left.-{ }^{3} \mathrm{H}\right]$ choline phosphate. Reactions in incubation mixtures (see Results) were terminated by adding $3 \mathrm{vol}$. ethanol, mixing thoroughly and cooling in ice, and the insoluble material was removed by centrifugation. The supernatant fluid, which contained almost all of the ${ }^{3} \mathrm{H}$, was dried by rotary evaporation in a small tube. The dried material was redissolved in $30 \mu \mathrm{l}$ ethanol/water $(\mathrm{I}: 2, \mathrm{v} / \mathrm{v})$ and $\mathrm{I} 0 \mu \mathrm{l}$ samples were applied to Whatman no. I paper. Electrophoresis in buffer A was carried out for $30 \mathrm{~min}$ at $45 \mathrm{~V} \mathrm{~cm}^{-1}$. Areas of the paper corresponding to standard choline phosphate were cut out and assayed for radioactivity in a scintillation fluid [containing $0.4 \%(\mathrm{w} / \mathrm{v})$ 2,5-diphenyloxazole (PPO) and $0.01 \%$ (w/v) I,4-bis(4-methyl-5-phenyloxazol-2-yl)benzene (dimethyl POPOP) in toluene] using a Packard Tri-Carb model 3385 liquid scintillation spectrometer.

Assay of $\left[\right.$ methyl $\left.{ }^{3} \mathrm{H}\right] \mathrm{CDP}$ choline. Incubation mixtures were treated as for the choline phosphate assay except, instead of electrophoresis, samples were chromatographed in solvent $\mathrm{C}$ and areas corresponding to standard CDPcholine were assayed for radioactivity.

\section{RESULTS}

\section{Metabolites of $\left[{ }^{3} \mathrm{H}\right]$ choline in whole bacteria}

The defined medium of Tomasz (1964) (100 ml, containing Io $\mu \mathrm{Ci}\left[\right.$ methyl ${ }^{3} \mathrm{H}$ ]choline chloride) was inoculated with one loopful of $S$. pneumoniae and incubated statically for I $6 \mathrm{~h}$ at $37^{\circ} \mathrm{C}$. The bacteria were then washed twice with ice-cold $0.9 \% \mathrm{NaCl}$, once with distilled water and then extracted with $20 \mathrm{ml} 5 \%$ (w/v) trichloroacetic acid (TCA) for $30 \mathrm{~min}$ at $4{ }^{\circ} \mathrm{C}$. The extract was separated by centrifuging at $10000 \mathrm{~g}$ for $15 \mathrm{~min}$ and the 

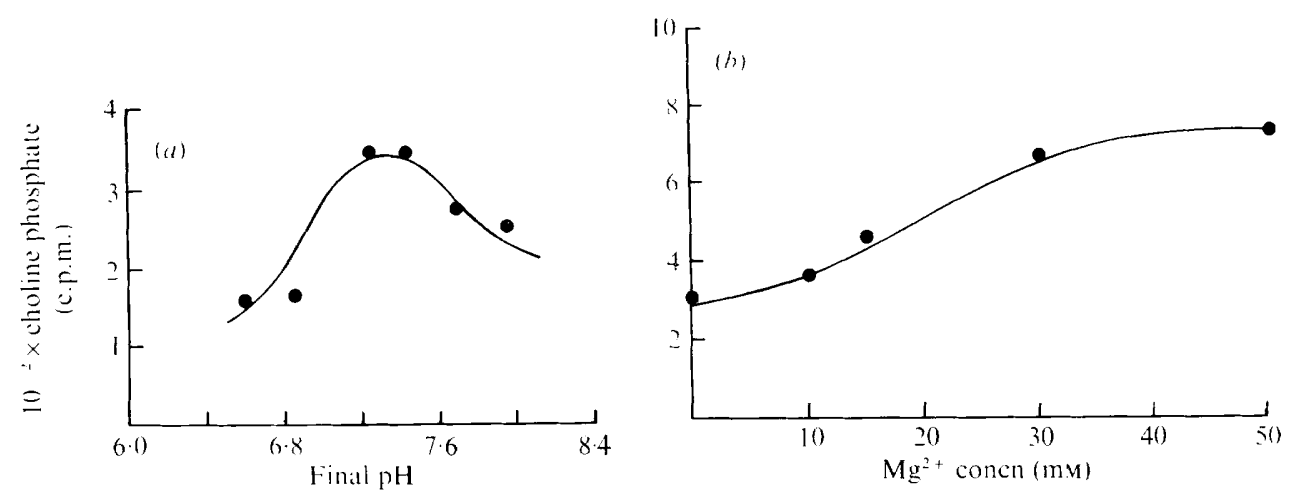

Fig. I. (a) $\mathrm{pH}$ profile of choline kinase. Incubation mixtures ( $1.0 \mathrm{ml}$ ) containing $0.5 \mathrm{ml}$ crude enzyme ( $8 \mathrm{mg}$ protein), $0.2 \mathrm{ml} 80 \mathrm{mM}$-veronal/ $\mathrm{HCl}$ buffer, and (final concentrations) $0.04 \%(\mathrm{w} / \mathrm{v}$ ) 2-mercaptoethanol, $10 \mathrm{~mm}-\mathrm{Na}_{2} \mathrm{HPO}_{4}$ and $10 \mathrm{mM}-\mathrm{ATP}$, were incubated at $37^{\circ} \mathrm{C}$ with $0.1 \mathrm{ml} 40 \mathrm{~mm}$ $\left[\right.$ methyl $\left.-{ }^{3} \mathrm{H}\right]$ choline chloride $\left(0.5 \mu \mathrm{Ci} \mu \mathrm{mol}^{-1}\right)$. After $20 \mathrm{~min}$, duplicate $0.2 \mathrm{ml}$ samples were assayed for choline phosphate and the $\mathrm{pH}$ value of the remainder was determined. (b) Magnesium ion dependence of choline kinase. $\mathrm{MgCl}_{2}$ was added at (final concentrations) $0,10,15,30$ and $50 \mathrm{~mm}$ to $0.25 \mathrm{ml}$ of an incubation mixture similar to that in $(a)$. The whole incubation mixture was assayed for choline phosphate.

TCA was removed by six extractions with an equal volume of ether. Finally the extract was concentrated by rotary evaporation and chromatographed as a $2 \times 0.5 \mathrm{~cm}$ band on Whatman no. I paper in solvent $C$. The distribution of radioactivity on the chromatogram was investigated by cutting the paper into $\mathrm{I} \mathrm{cm}$ strips and measuring their radioactivity in a scintillation spectrometer. Results showed that $85 \%$ of the radioactivity co-chromatographed with an authentic choline phosphate standard, II \% co-chromatographed with CDPcholine and $4 \%$ remained at the origin. No free choline was observed.

\section{Cell-free studies on the enzymes of choline metabolism}

Choline kinase (EC 2.7.I.32). In a preliminary experiment, choline, ATP and the crude enzyme were incubated together in a buffered system under conditions similar to those described in Fig. I. Samples, taken at intervals over $60 \mathrm{~min}$, showed a plateau for choline phosphate formation after about $30 \mathrm{~min}$. This incubation mixture was then used as a basis for determining the optimum reaction conditions for the choline kinase. The enzyme had a $\mathrm{pH}$ optimum of between $7 \cdot 3$ and $7 \cdot 4$ (Fig. I $a$ ), and its activity reached a maximum when incubated with about $30 \mathrm{~mm}-\mathrm{Mg}^{2+}$ (Fig. I $b$ ).

The kinetic properties of the pneumococcal choline kinase were examined for comparison with the corresponding yeast enzyme. Under the previously determined optimum conditions, the reaction choline $\rightarrow$ choline phosphate did not proceed any further (i.e. to the choline nucleotide). The enzyme's dependence on choline concentration was therefore investigated as follows: [methyl ${ }^{3} \mathrm{H}$ ]choline chloride, at between 0 and $3 \mathrm{~mm}$, was incubated with the crude enzyme suspension for $20 \mathrm{~min}$ at $37^{\circ} \mathrm{C}$ with $3 \mathrm{~mm}$-ATP. Choline phosphate was assayed and the enzyme activity was related to the substrate concentration by both direct and double reciprocal plots (Fig. 2a). A $V_{\max }$ of $0.5 \mathrm{nmol} \mathrm{m^{-1 }}$ (mg protein) ${ }^{-1}$ was obtained, with an apparent $K_{\mathrm{m}}$ of $0.19 \mathrm{mM}$. Using a constant choline concentration, and varying the ATP between 0 and $20 \mathrm{mM}$, the two plots of enzyme activity (Fig. $2 b$ ) showed that the substrate (ATP) strongly inhibited the enzyme at above $2.5 \mathrm{~mm}$. Identical results were obtained with either 5 or $20 \mathrm{~mm}-\mathrm{Mg}^{2+}$, so the effect was not due to magnesium 

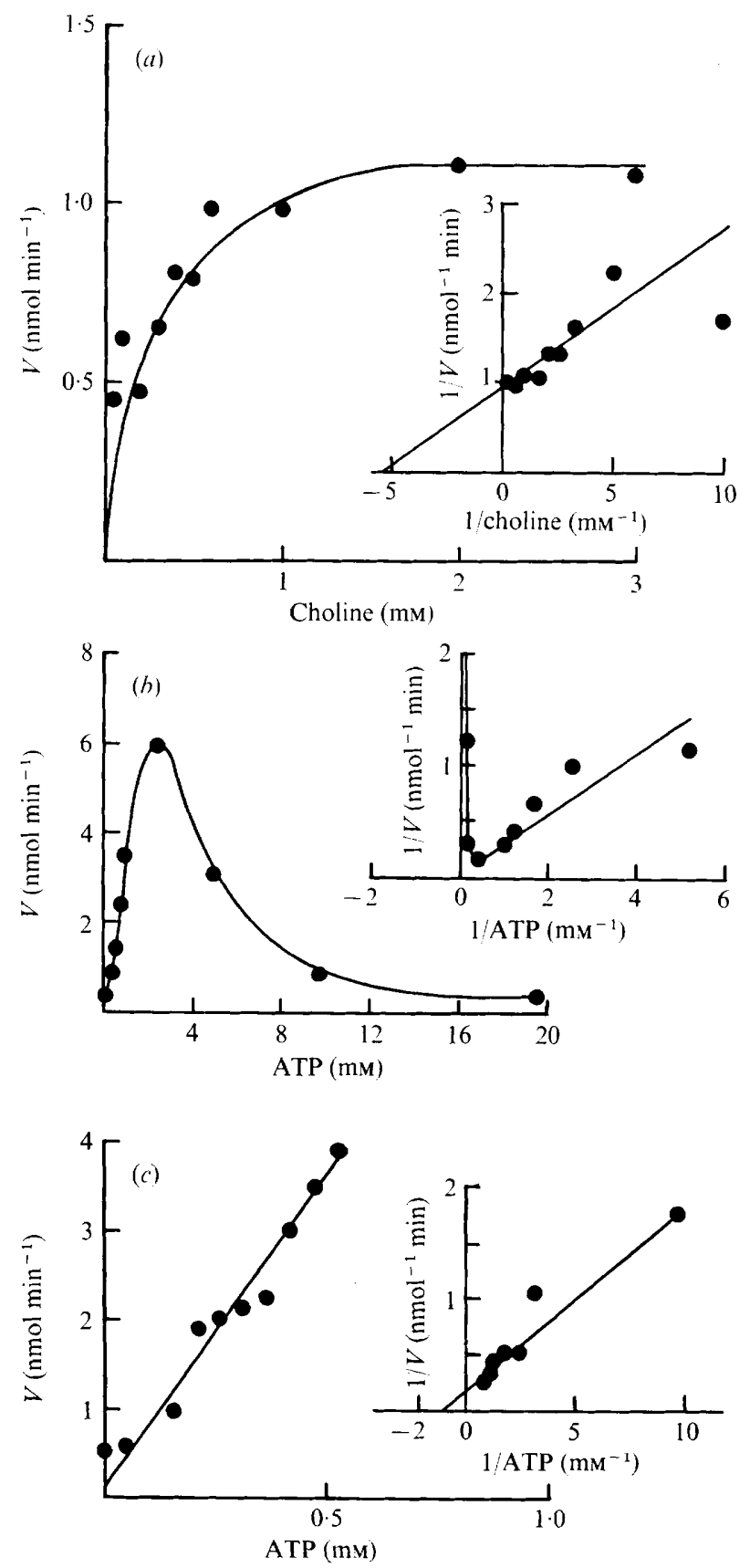

Fig. 2. Kinetics of pneumococcal choline kinase. Incubation mixtures $(0.25 \mathrm{ml})$ contained I $25 \mu \mathrm{l}$ crude enzyme ( $2 \mathrm{mg}$ protein) and (final concentrations) $40 \mathrm{mM}$-veronal/ $\mathrm{HCl}$ buffer, $\mathrm{pH} 7.4,0.0 \mathrm{I} \%$

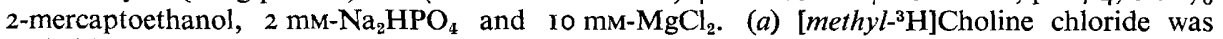
varied between $o$ and $3 \mathrm{~mm}$ with ATP constant at $3 \mathrm{~mm}$. After $20 \mathrm{~min}$ at $37^{\circ} \mathrm{C}$, the whole mixture was assayed for choline phosphate. Results are plotted directly and as a double reciprocal plot (inset). (b) and (c) Similar incubation mixtures were used except the concentration of [methyl $\left.{ }^{3} \mathrm{H}\right]-$ choline chloride was kept constant at $10 \mathrm{mM}$ and ATP was varied between 0 and 20 mM (Fig. $2 b$ ) and $O$ and I mM (Fig. 2c). 


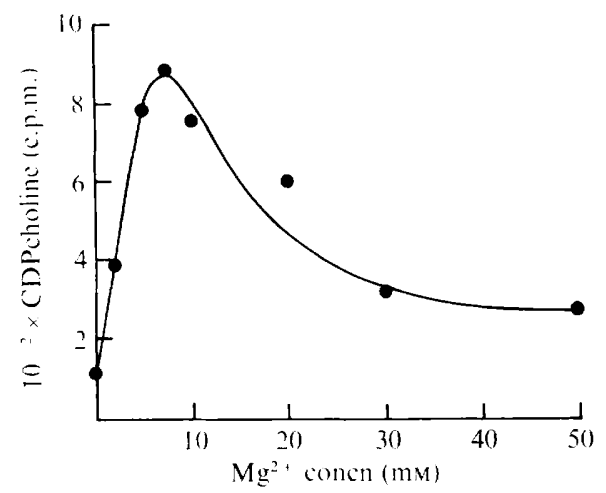

Fig. 3. Magnesium ion dependence of CDPcholine pyrophosphorylase. $\mathrm{MgCl}_{2}$ was varied between 0 and $50 \mathrm{~mm}$ in incubation mixtures $(0.25 \mathrm{ml})$ containing $60 \mu \mathrm{l}$ crude enzyme, $120 \mu 180 \mathrm{~mm}$-veronal/

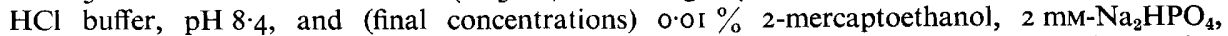
ro mM-CTP and 10 mM- $\left[\right.$ methyl $\left.^{-3} \mathrm{H}\right]$ choline phosphate $\left(0.06 \mu \mathrm{Ci} \mu \mathrm{mol}^{-1}\right)$. After $20 \mathrm{~min}$ incubation at $37^{\circ} \mathrm{C}$, the whole incubation mixture was assayed for CDPcholine.

limitation. In a further experiment, in which ATP was varied between o and I mM, more accurate determinations gave $V_{\max }$ as 3 to $3.2 \mathrm{nmol} \mathrm{min}^{-1}$ (mg protein) ${ }^{-1}$ and $K_{\mathrm{m}}$ as I mM (Fig. 2c).

Although no steps have been taken to purify the choline kinase in this study, we found that if the crude enzyme was centrifuged at $100000 \mathrm{~g}$ for $\mathrm{I} \mathrm{h}$, about $90 \%$ of the enzyme activity per unit protein remained in the supernatant fluid.

CDPcholine pyrophosphorylase (EC 2.7.7.-). The experiment summarized above indicated that a choline nucleotide, with the same $R_{F}$ as CDPcholine, was one of the metabolic products of choline. A preliminary experiment showed that CDPcholine could be synthesized in a cell-free system from choline phosphate and CTP: a mixture ( $1 \cdot 0 \mathrm{ml})$ containing $0.5 \mathrm{ml}$ crude enzyme, $20 \mathrm{~mm}$-veronal/ $\mathrm{HCl}$ buffer, $\mathrm{pH} 8.4,0.01 \%$ 2-mercaptoethanol,

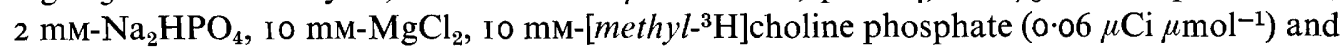
Io mM-CTP was incubated for $50 \mathrm{~min}$ at $37^{\circ} \mathrm{C}$ and $0.2 \mathrm{ml}$ samples were taken at intervals and assayed for CDPcholine. The level of CDPcholine was observed to increase, reaching a plateau after about $30 \mathrm{~min}$ incubation.

CTP was a specific requirement of this enzyme. When it was replaced in the above incubation mixture by UTP, GTP or ATP at $10 \mathrm{~mm}$ and, after $30 \mathrm{~min}$ incubation, the whole mixture was assayed for choline nucleotides by chromatography in solvent $\mathrm{C}$, no radioactivity was detected in the region between the origin and choline phosphate (where a choline nucleotide would be expected to run).

Using the incubation mixture described in Fig. 3 and varying $\mathrm{Mg}^{2+}$ between 0 and $50 \mathrm{~mm}$, the maximum activity of the CDPcholine pyrophosphorylase was found with 7 mM-Mg2+ (Fig. 3).

No kinetic experiments were carried out on the CDPcholine pyrophosphorylase. Preliminary experiments on the crude enzyme system indicated that the reaction was not a simple one-step reaction. A variable amount of radioactivity, which could possibly be polymeric material, was always found at the origin. However, no free choline was found indicating the absence of a phosphatase. 


\section{DISCUSSION}

The pneumococcus appears unique among bacteria in having choline in its cell wall. Choline is found widely in eukaryotic organisms as part of the phospholipid phosphatidylcholine (lecithin). This phospholipid is, however, relatively uncommon among bacteria (Hagen, Goldfine \& Williams, 1966). Phosphatidylcholine is synthesized by two pathways in eukaryotes (Kennedy, 1962): (i) from CDP-D-I,2-diglyceride via phosphatidyl serine and phosphatidyl ethanolamine; or (ii) from choline via choline phosphate and CDPcholine plus D-I,2-diglyceride. There is evidence that both pathways occur in yeasts (Hunter \& Rose, I971 ; Brostrom \& Browning, 1973), while the latter seems to be predominantly found in mammalian and plant systems. The metabolism of choline in the pneumococcus appears to be similar to the first two steps in pathway (ii). Tomasz (1967) has shown that ethanolamine cannot be methylated to choline by the pneumococcus.

The kinetics of the yeast choline kinase have been investigated by Brostrom \& Browning (1973). The results obtained for the pneumococcal choline kinase, however, differ to some extent; the apparent Michaelis constant $\left(K_{\mathrm{m}}\right)$ with respect to choline was $190 \mu \mathrm{M}$ for the pneumococcus and $15 \mu \mathrm{M}$ for the yeast, whereas $K_{\mathrm{m}}$ with respect to ATP was I 0 mM for the pneumococcus and $0.14 \mathrm{~mm}$ for the yeast. The $\mathrm{pH}$ optima also differ, that for the yeast being 8.5 to 9.5 compared with $7 \cdot 3$ to $7 \cdot 4$ for the pneumococcus. Both enzymes require magnesium. It should be noted that the yeast enzyme was partially purified and that $K_{\mathrm{m}}$ for the pneumococcal enzyme, especially with respect to ATP concentration, will be inaccurate as ATP will be metabolized in other ways. The assay procedure for the pneumococcal enzyme was simple and perhaps more reproducible than that used for the yeast enzyme.

Possibly the uptake of choline by $S$. pneumoniae involves the action of the kinase as there is no pool of free choline inside the cell. This could, however, be due to the bacteria being in the stationary phase of growth.

We propose that CDPcholine, which is synthesized from choline phosphate, is the direct precursor of the choline which is incorporated into pneumococcal C-teichoic acid. As not every repeating unit of $\mathrm{C}$-teichoic acid is substituted with choline (I. R. Poxton \& J. Baddiley, unpublished results), the control of choline substitution is probably at the level of the choline kinase or the CDPcholine pyrophosphorylase, possibly in combination with the phosphorylcholine esterase described by Holtje \& Tomasz (1974).

In an independent study, Bean \& Tomasz have shown that choline phosphate and CDPcholine are metabolic products of choline in the pneumococcus (B. Bean \& A. Tomasz, unpublished results).

This work was supported by the Medical Research Council. D. J. Leak acknowledges the award of a Science Research Council studentship. We thank Professor Baddiley, in whose laboratory this work was carried out, for his interest.

\section{REFERENCES}

Bregoff, H. M., Roberts, E. \& Delwiche, C. C. (1953). Paper chromatography of quaternary ammonium bases and related compounds. Journal of Biological Chemistry 205, 565-574.

Briles, E. B. \& Tomasz, A. (I973) Pneumococcal Forssman antigen - a choline containing lipoteichoic acid. Journal of Biological Chemistry 248, 6394-6397.

Brostrom, M. A. \& Browning, E. T. (1973). Choline kinase from Brewers' Yeast. Journal of Biological Chemistry 248, 2364-237I.

Brundish, D. E. \& Baddiley, J. (I968). Pneumococcal C-substance, a ribitol teichoic acid containing choline phosphate. Biochemical Journal 110, 573-582. 
Hagen, P-O., Goldfine, H. \& Williams, P. J. LeB. (1966). Phospholipids of bacteria with extensive intracytoplasmic membranes. Science r5I, I $543^{-1} 544$.

Holtje, J. V. \& Tomasz, A. (1974). Teichoic acid phosphoryl-choline esterase. A novel enzyme activity in pneumococcus. Journal of Biological Chemistry 249, 7032-7034.

Hunter, K. \& Rose, A. H. (197I). Yeast lipids and membranes. In The Yeasts, vol. 2, pp. 21 I-270. Edited by A. H. Rose and J. S. Harrison. London: Academic Press.

KENNEDY, E. P. (1962). The metabolism and function of complex lipids. Harvey Lectures, Series 57, I41-I 7I.

Lowry, O. H., Rosebrough, N. J., Farr, A. L. \& Randall, R. J. (I95I). Protein measurement with the Folin phenol reagent. Journal of Biological Chemistry 193, 265-275.

Rane, L. \& Subbarow, Y. (1940). Nutritional requirements of the Pneumococcus. I. Growth factors for types I, II, V, VII and VIII. Journal of Bacteriology 40, 695-704.

RILEY, R. F. (1944). Metabolism of phosphoryl choline. I. Synthesis of calcium phosphorylcholine chloride containing the radioactive isotope $\mathrm{P}^{32}$. Journal of the American Chemical Society 66, 5I 2-5I3.

Tomasz, A. (1964). Studies on the competence (for genetic transformation) of Diplococcus pneumoniae in a synthetic medium. Bacteriological Proceedings 29, 29.

Tomasz, A. (I967). Choline in the cell wall of a bacterium: novel type of polymer-linked choline in pneumococcus. Science 157, 694-697.

Tomasz, A. (I968). Biological consequences of the replacement of choline by ethanolamine in the cell wall of pneumococcus. Proceedings of the National Academy of Sciences of the United States of America 59, 86-93.

Tomasz, A., Westrhal, M., Briles, E. B. \& Fletcher, P. (1975). On the physiological functions of teichoic acids. Journal of Supramolecular Structure 3, I-16. 